\title{
INTEGRATED MANAGEMENT OF FUSARIUM SPP. ASSOCIATED WITH CHICKPEA (CICER ARIETINUM L.) WILT DISEASE IN THE PUNJAB, PAKISTAN
}

\author{
FATIMA, K. ${ }^{1}-$ HABIB, A. ${ }^{*}-$ SAHI, S. T. ${ }^{1}-$ CHEEMA, H. M. N. ${ }^{2}$ \\ ${ }^{1}$ Department of Plant Pathology, University of Agriculture, Faisalabad, Pakistan \\ ${ }^{2}$ Department of Plant Breeding \& Genetics, University of Agriculture, Faisalabad, Pakistan \\ *Corresponding author \\ e-mail: amer.habib@uaf.edu.pk; phone:+92-333-650-4965
}

(Received $1^{\text {st }}$ Sep 2021; accepted $23^{\text {rd }}$ Nov 2021)

\begin{abstract}
Chickpea (Cicer arietinum L.) is the third most significant crop grown in Pakistan. This crop is a rich source of protein and carbohydrates. In developing countries, civilians are facing dietary protein shortage problems due to limited resources. Animals' products, including beef, fish, meat and eggs are major sources of proteins which are too expensive to buy for the poor. In Pakistan, it is mostly cultivated in arid/semi-arid areas of the Thal region of Punjab province. These areas are totally dependent on rainfall for water requirements. Fortunately, chickpea is a drought tolerant crop but some biotic factors are also involved in low production of chickpea crop. Gram wilt disease is one of the major threats to this crop. Considering the current situation, it is necessary to develop sustainable management strategies. This study was planned with the aim of long-term management strategies against fungal pathogen associated with wilt disease including determination of resistant resources among the available genetic material, among three biocontrol agents Trichoderma harzianum showed maximum inhibition under in vitro and in vivo conditions and among ten chemicals, score showed maximum inhibition of Fusarium spp. which was followed by Topsin $\mathrm{M}$ and Baviston under in vitro and in vivo conditions.
\end{abstract}

Keywords: resistant resources, biocontrol, chemical control, T. harzianum, score

\section{Introduction}

Chickpea (Cicer arietinum L.) is a nutritive pulse crop that is grown under arid and semi-arid conditions worldwide (Millan et al., 2006). Legume crops enhance the fertility of soil by fixing the atmospheric nitrogen with the help of rhizobia which are present inside the nodules. Soybean, pea, bean, alfalfa, clover and chickpea are included concerning legumes. Legumes play important roles in several factors like salt tolerance, nitrogen fixation and soil fertility (Graham and Vance, 2003). Chickpea fulfills $80 \%$ of nitrogen requirement of crop and fixes $140 \mathrm{~kg}$ air nitrogen/hectare through symbiotic relationship with rhizobia, and is the major source of nitrogen for the consequent crops. Chickpea also increases organic matter in soil and results in the long-standing fertility of soil and plays a vital role in the sustainability of the ecosystem. Chickpea has now specialty in to the restaurants and health shops. It is now used in occasional stuffs in restaurants and has widened its range. Kabuli chickpea is an obligatory part of bean salad and salad bars in North America. Chickpea's huge amount is mainly used for several types of dishes in Mediterranean region, India and Burma. Mostly vegetarians use chickpea as food intake. Almost ninety percent losses in the yield are caused by root based diseases as well as by pathogens like fungi (Zamani et al., 2004: Haware, 1990; Sharma and Muehlbauer, 2007). Pathogenic fungi that affect roots include mainly Fusarium oxysporum, Macrophomina phaseolina, Fusarium solani and Rhizoctonia solani. The pathogens remain active even in the absence of its host for a period of more 
than six years although they are seed borne (Haware et al., 1996; Ayyub et al., 2003). Fungal diseases are causing more disaster in chickpea crop due to the production of constant mycotoxins. Therefore, to reduce the chickpea disasters, it is necessary to control the fungal growth (Yan et al., 2015). Fusarium wilt is a serious disease of Pakistan, Nepal, Burma, Spain and Maxico. Chickpea wilt causes 61\% damage at seedling stage and $43 \%$ at flowering stage (Nema et al., 1973). This disease causes 10$50 \%$ loss in chickpea production in Pakistan every year (Khan et al., 2002). Seeds of early wilted crop are lighter in weight and have dull appearance as compare to healthy crop (Haware and Nene, 1980). During reproductive and vegetative stage, chickpea wilt causes complete destruction of grain production (Navas et al., 2000). The pathogen of chickpea wilt disease mainly spread through soil in plant and can also be transmitted through seed. This pathogen survives in soil for six years without host (Haware et al., 1986). Fusarium oxysporum is difficult to control but resistant varieties are used for this purpose. Resistant varieties become susceptible to new races of pathogen after few years due to which this management strategy is difficult to use. Because the pathogen remains viable for long period of time and preparation of new resistant variety takes time to enter in market and losses becomes obvious. So, use of fungicides is most suitable for Fusarium wilt management (Gupta et al., 1988).

\section{Materials and methods}

Chickpea fields were visited in Thal region of Punjab, Pakistan for finding the diseased plants infected with Fusarium spp. associated with chickpea roots. Fusarium spp. were isolated from diseased sample and were stored in double ionized distilled water for further studies and most aggressive isolate after pathogenicity and molecular characterization was used for implementation of management strategies. For the completion of all experiments, field, greenhouse and laboratories of the department of plant pathology and CABB in the University of Agriculture, Faisalabad was used in 2017-2018.

\section{Chickpea germplasm collection for resistance/susceptibility evaluation}

Collection of chickpea varieties from seed agencies and from local markets was done to find out the most resistant cultivars (that can be used by farmers to get more production by growing these varieties in field). These varieties were under examination for two years. These plants were inoculated with Fusarium spp. and resistance of chickpea varieties was observed. $10 \mathrm{ml}$ inoculum was added in soil near root zone of plants and these plants were stored in greenhouse at $25^{\circ} \mathrm{C}$ for 3 weeks. Data was recorded after $1^{\text {st }}, 2^{\text {nd }}$ and $3^{\text {rd }}$ week of inoculation in green house.

\section{In vivo and in vitro management of Fusarium spp. by using fungal antagonists:}

Three fungal antagonists Trichoderma harzianum, Trichoderma viride and Trichoderma virens were evaluated against Fusarium spp. associated with chickpea wilt by using dual culture technique (Atta et al., 2009). In petri dish containing PDA, $9 \mathrm{~mm}$ culture of both Fusarium spp. and antagonists were placed in petri dish at the distance of $5 \mathrm{~mm}$ from the edge of plate and control plate had only fungal pathogen. Three replications of each treatment were used with one control. Experiment was repeated three times. These plates were incubated at $25 \pm 2{ }^{\circ} \mathrm{C}$. Data was recorded after 24,48 and $96 \mathrm{~h}$ of inoculation. Following formula was used for percent inhibition (Vincent, 1947): 


$$
\text { Percent Growth Inhibition }(\mathrm{PI})=\frac{\mathrm{C}-\mathrm{T}}{\mathrm{C}} \times 100
$$

where: $\mathrm{C}=$ Colony growth in control plate; $\mathrm{T}=$ Colony growth in treated plate.

In vivo evaluation of fungal antagonists (Trichoderma harzianum, Trichoderma viride and Trichoderma virens) was done under greenhouse conditions against most virulent Fusarium spp. soil was treated with these antagonists at the concentrations of $1 \times 10^{8} \mathrm{cfu} / \mathrm{ml}, 1 \times 10^{16} \mathrm{cfu} / \mathrm{ml}$ and $1 \times 10^{24} \mathrm{cfu} / \mathrm{ml}$ before one week of inoculation of Fusarium spp. Cultures were prepared on PDA. Four treatments were used with three replications. Culture suspension $1 \times 10^{7} \mathrm{cfu} / \mathrm{ml}$ of Fusarium spp. was prepared for inoculation of soil and was applied by using soil drenching technique in the greenhouse.

\section{In vivo and in vitro management of Fusarium spp. by using fungicides}

In this experiment 10 different systemic and contact fungicides were used with 3 replications and 1 control. Ten fungicides Score, Topsin M, Baviston, Chlorothalonil, Stump, Big Time, Champion, Velvet, Curzate M8 and Co-oxy were checked out against Fusarium spp. by using Poison Food Technique (Nene and Thapliyal, 1982). These ten fungicides were evaluated at three concentrations (100, 150 and $200 \mathrm{ppm}$ ):

\begin{tabular}{c|c|c|c|c|c|c}
\hline $\begin{array}{c}\text { Sr. } \\
\text { No. }\end{array}$ & Chemical name & Trade name & Active ingredients & Mode of action & Formulation & $\begin{array}{c}\text { Manufacturing } \\
\text { company }\end{array}$ \\
\hline 1 & Score & Score & Difenoconazole & Systemic & 250 SC & Syngenta Pakistan \\
2 & Topsin-M & Nativo & Trifloxystrobin + tebuconazole & Systemic & $75 \%$ WG & Bayer Pakistan \\
3 & Baviston & Baviston & Carbendazim & Systemic & $50 \%$ DF & KANZO \\
4 & Chlorothalonil & Chlorothalonil & Chlorothalonil & Contact & $75 \%$ WP & Synenta Pakistan \\
5 & Stump & Stump & Propineb & Contact & $70 \%$ WP & FMC \\
6 & Big Time & Big Time & Mancozeb, Dithane M-45 & Systemic & $80 \%$ WP & Arysta Life Science \\
7 & Champion & Champion & Copper hydro oxide & Contact & $77 \%$ WP & Jaffar Agros \\
8 & Velvet & Velvet & Fosetyl-aluminium + mancozeb & Systemic & $80 \%$ WP & Welcone \\
9 & Curzate-M8 & Curzate-M8 & Mencozeb + cymoxanil & Protective & $72.5 \%$ WDG & Arysta Life Science \\
10 & Co-oxy & Co-oxy & Copper oxychloride & Contact & $50 \%$ WP & Swat Agro Chemicals \\
\hline
\end{tabular}

Pure culture Fusarium spp. was used for evaluation. Stock solutions were prepared to get different concentrations (100, 200 and $300 \mathrm{ppm})$ according to active ingredient of fungicides followed by the method used by Rehman et al. (2018) and then were added in $200 \mathrm{ml}$ of potato dextrose agar. All the procedure was completed in laminar flow cabinet (ESCO) to avoid contamination. $20 \mathrm{ml}$ of prepared PDA containing fungicides at different concentrations was poured in $90 \mathrm{~mm}$ petri dishes. Control plates were also prepared by pouring $20 \mathrm{ml}$ PDA without fungicides in petri plates. After solidification of PDA in petri plates, these petri dishes were inoculated by $4 \mathrm{~mm}$ block of PDA having pure culture of Fusarium spp. (7 days old culture). with the help of sterilized cork borer and these dishes were incubated at $25 \pm 2{ }^{\circ} \mathrm{C}$ in an incubator. Radial culture growth $(\mathrm{mm})$ of different Fusarium spp. was recorded after 7, 14 and 21 days of inoculation. Percent inhibition growth was calculated by above given formula. In vivo management was done by using most effective fungicides (Score, Topsin $\mathrm{M}$ and Baviston) at different concentration like 100, 200 and $300 \mathrm{ppm}$ with three replications and one control in green house. Seeds were surface sterilized and soaked in distilled water for overnight to soften the seed coat for facilitation of pathogen penetration, Autoclaved pots were filled with disinfected soil, this soil was infested with most virulent Fusarium spp. by mixing soil with mass culture of 
fungus. And 5 autoclaved seeds were sown 2 to $3 \mathrm{~cm}$ deep in each pot containing soil. All these experimental materials were laid down under CRD (Complete Randomized Design) in factorial arrangement with three replications. Aqueous suspension of most effective fungicides was added in pots by drenching the soil. Data was recorded after 40 days of application of fungicide and analyzed to find out the difference between treatments by using the statistic software version 8.1.

\section{Results}

\section{Screening of chickpea germplasm against most aggressive Fusarium spp.}

Twenty varieties were screen out against fusarium wilt of chickpea under greenhouse condition for two years. Data recorded during 2017 and 2018 showed that no variety was found immune against fusarium wilt. During $1^{\text {st }}$ year two varieties incidence exhibited highly resistant response, while six varieties showed resistant response against fusarium wilt. Four varieties showed moderately resistant response whereas five varieties gave susceptible response against fusarium wilt. However, three varieties were highly susceptible (Table 1.). Study, during $2^{\text {nd }}$ year, revealed that same three varieties were highly susceptible like first year. Five varieties exhibited susceptible response. Four varieties showed moderately resistant response. Six varieties showed resistant response against fusarium wilt. Two varieties gave highly resistant response (Table 1).

Table 1. Two years response of chickpea germplasm against most aggressive isolate (NK32, Fusarium oxysporum (FOK1) from Layyah) (HR = highly resistant, $R=$ resistant,

$M R=$ moderately resistant,$S=$ susceptible and $H S=$ highly susceptible)

\begin{tabular}{c|c|c|c|c}
\hline \multirow{2}{*}{ Variety } & \multicolumn{2}{|c|}{ Year 1 } & \multicolumn{2}{c}{ Year 2 } \\
\cline { 2 - 5 } & Disease incidence (\%) & Response & Disease incidence (\%) & Response \\
\hline Dasht & $54.667 \mathrm{~B}$ & $\mathrm{HS}$ & $55.667 \mathrm{~A}$ & $\mathrm{HS}$ \\
Thal 2006 & $53.000 \mathrm{~B}$ & $\mathrm{HS}$ & $52.000 \mathrm{~B}$ & $\mathrm{HS}$ \\
AUG-424 & $57.667 \mathrm{~A}$ & $\mathrm{HS}$ & $56.667 \mathrm{~A}$ & $\mathrm{HS}$ \\
Balkasar & $0.1667 \mathrm{M}$ & $\mathrm{HR}$ & $0.2333 \mathrm{~J}$ & $\mathrm{HR}$ \\
Bittle 98 & $5.6667 \mathrm{KL}$ & $\mathrm{R}$ & $6.6667 \mathrm{HI}$ & $\mathrm{R}$ \\
CMC211S & $14.667 \mathrm{HI}$ & $\mathrm{MR}$ & $15.667 \mathrm{~F}$ & $\mathrm{MR}$ \\
CM-98 & $13.667 \mathrm{I}$ & $\mathrm{MR}$ & $12.667 \mathrm{G}$ & $\mathrm{MR}$ \\
CM-88 & $12.333 \mathrm{I}$ & $\mathrm{MR}$ & $12.667 \mathrm{G}$ & $\mathrm{MR}$ \\
C-44 & $4.3333 \mathrm{~L}$ & $\mathrm{R}$ & $5.0000 \mathrm{I}$ & $\mathrm{R}$ \\
C-727 & $0.3000 \mathrm{M}$ & $\mathrm{HR}$ & $0.4333 \mathrm{~J}$ & $\mathrm{HR}$ \\
Punjab-91 & $4.6667 \mathrm{KL}$ & $\mathrm{R}$ & $5.3333 \mathrm{I}$ & $\mathrm{R}$ \\
AUG-785 & $5.3333 \mathrm{KL}$ & $\mathrm{R}$ & $4.3333 \mathrm{I}$ & $\mathrm{R}$ \\
Parbat & $45.000 \mathrm{C}$ & $\mathrm{S}$ & $43.667 \mathrm{C}$ & $\mathrm{S}$ \\
Noor-91 & $17.333 \mathrm{H}$ & $\mathrm{MR}$ & $17.667 \mathrm{~F}$ & $\mathrm{MR}$ \\
PB-1 & $40.667 \mathrm{D}$ & $\mathrm{S}$ & $42.333 \mathrm{C}$ & $\mathrm{S}$ \\
C-235 & $7.3333 \mathrm{JK}$ & $\mathrm{R}$ & $6.3333 \mathrm{HI}$ & $\mathrm{R}$ \\
PB200 & $36.000 \mathrm{E}$ & $\mathrm{S}$ & $35.333 \mathrm{D}$ & $\mathrm{S}$ \\
DC1 & $30.000 \mathrm{~F}$ & $\mathrm{~S}$ & $28.667 \mathrm{E}$ & $\mathrm{S}$ \\
CM72 & $8.6667 \mathrm{~J}$ & $\mathrm{R}$ & $8.3333 \mathrm{H}$ & $\mathrm{R}$ \\
ILC95 & $25.333 \mathrm{G}$ & $\mathrm{S}$ & $27.667 \mathrm{E}$ & $\mathrm{S}$ \\
LSD $(\boldsymbol{p} \leq \mathbf{0 . 0 5})$ & $2.85^{* *}$ & & $2.70 * *$ & \\
\hline
\end{tabular}




\section{In vivo and in vitro disease management by using fungal antagonists}

In the greenhouse study, various antagonists viz. Trichoderma harzianum, Trichoderma viride and Trichoderma virens applied at various concentrations significantly $(p \leq 0.05)$ reduced the disease incidence (\%) with respect to different days. Disease incidence (\%) was maximum (15.50\%) in case of Trichoderma virens followed by Trichoderma viride (13.98\%) and Trichoderma harzianum (12.48\%) over control (35.06\%). Regarding various concentrations, maximum disease incidence (20.98\%) was observed where $1 \times 10^{24}(\mathrm{cfu} / \mathrm{ml})$ concentration was applied as compared to $1 \times 10^{16}$ $(\mathrm{cfu} / \mathrm{ml})(19.71 \%)$ and $1 \times 10^{8}(\mathrm{cfu} / \mathrm{ml})(17.06 \%)$. Disease incidence was at its peak at day $3^{\text {rd }}(20.41 \%)$, whereas, minimum disease incidence was at day $1(18.51 \%)$ (Table 2). Regarding interaction between treatments and concentrations revealed that maximum reduction in disease incidence (\%) was assessed in case of Trichoderma harzianum $(10.77 \%, 12.83 \%, 13.83 \%)$, while, minimum reduction in disease incidence was exhibited in case of control $(31.54 \%, 35.87 \%, 37.76 \%)$ at $1 \times 10^{8}(\mathrm{cfu} / \mathrm{ml}), 1 \times 10^{16}$ $(\mathrm{cfu} / \mathrm{ml})$ and $1 \times 10^{24}(\mathrm{cfu} / \mathrm{ml})$ concentrations respectively. Interaction between concentrations and days revealed that maximum reduction in disease incidence (\%) was assessed in case of $1 \times 10^{8}(\mathrm{cfu} / \mathrm{ml})(15.2 \%, 16.85 \%, 19.14 \%)$, while, minimum reduction in disease incidence was exhibited in case of $1 \times 10^{24}(\mathrm{cfu} / \mathrm{ml})(20.51 \%$, $21.11 \%, 21.31 \%)$ at $1^{\text {st }}, 2^{\text {nd }}$ and $3^{\text {rd }}$ day respectively. Interaction between treatments, concentrations and days showed that disease incidence (\%) (10.33\%) was minimum where Trichoderma harzianum applied with $1 \times 10^{8}(\mathrm{cfu} / \mathrm{ml})$ concentrations at $1^{\text {st }}, 2^{\text {nd }}$ and $3^{\text {rd }}$ day. Disease incidence (\%) was maximum in control as compared to all other treatments at various days. Indication of variation within treatments to nullify the error chances within treatments presents as error bars (Figs. 1-3).

Table 2. Impact of various concentrations of Trichoderma spp. against Fusarium spp. under greenhouse condition

\begin{tabular}{|c|c|c|}
\hline Treatments (T) & Disease incidence (\%) & $\operatorname{LSD}(p \leq 0.05)$ \\
\hline Trichoderma harzianum & $12.48 \mathrm{D}$ & \multirow{4}{*}{0.85} \\
\hline Trichoderma viride & $13.98 \mathrm{C}$ & \\
\hline Trichoderma virens & $15.50 \mathrm{~B}$ & \\
\hline Control & $35.06 \mathrm{~A}$ & \\
\hline \multicolumn{3}{|c|}{ Concentration $(\mathrm{C})$} \\
\hline $1 \times 10^{8}(\mathrm{cfu} / \mathrm{ml})$ & $17.06 \mathrm{C}$ & \\
\hline $1 \times 10^{16}(\mathrm{cfu} / \mathrm{ml})$ & $19.71 \mathrm{~B}$ & 0.74 \\
\hline $1 \times 10^{24}(\mathrm{cfu} / \mathrm{ml})$ & $20.98 \mathrm{~A}$ & \\
\hline \multicolumn{3}{|c|}{ Days (D) } \\
\hline 1 & $18.51 \mathrm{~B}$ & \\
\hline 2 & $18.83 \mathrm{~B}$ & 0.74 \\
\hline 3 & $20.41 \mathrm{~A}$ & \\
\hline \multicolumn{3}{|c|}{$\operatorname{LSD}(p \leq 0.05)$} \\
\hline $\mathrm{T} \times \mathrm{C}$ & \multicolumn{2}{|c|}{ ** } \\
\hline$T \times D$ & \multicolumn{2}{|c|}{ NS } \\
\hline $\mathrm{C} \times \mathrm{D}$ & \multicolumn{2}{|c|}{$* *$} \\
\hline $\mathrm{T} \times \mathrm{C} \times \mathrm{D}$ & \multicolumn{2}{|c|}{$* *$} \\
\hline
\end{tabular}

Any two means within a column followed by same letters are not significant at $p \leq 0.05 . *=$ Significant at $p \leq 0.05 ; * *=$ Significant at $p \leq 0.01 ; \mathrm{NS}=$ Non-significant 
$\mathbf{\nabla} 1 \times 10^{8}(\mathrm{cfu} / \mathrm{ml}) \quad \boldsymbol{\square} 1 \times 10^{16}(\mathrm{cfu} / \mathrm{ml}) \quad \boldsymbol{\nabla} 1 \times 10^{24}(\mathrm{cfu} / \mathrm{ml})$

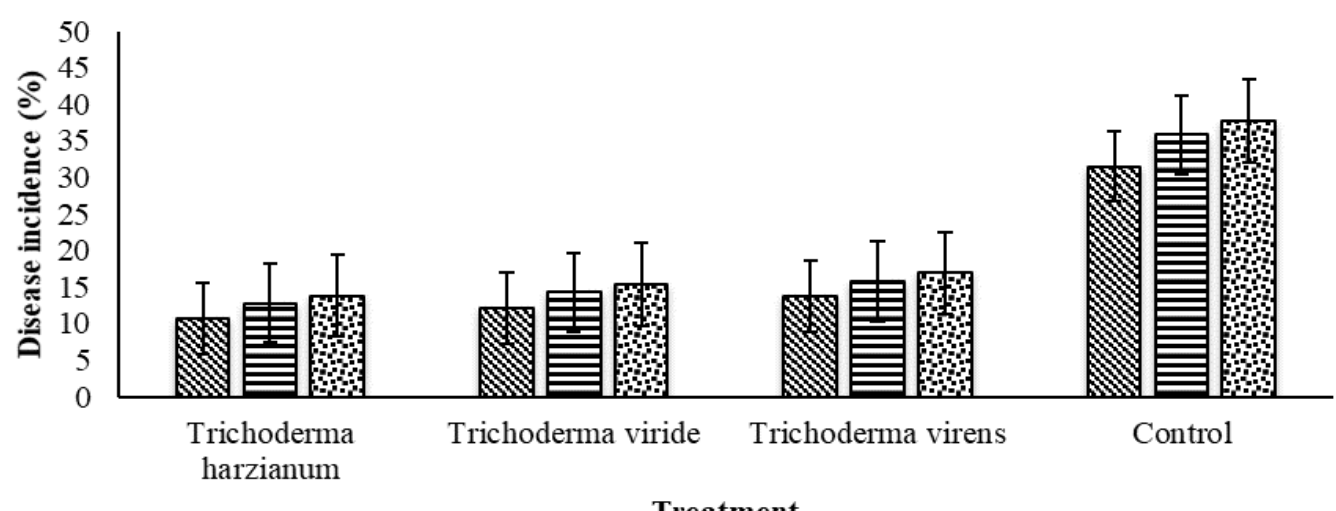

Figure 1. Variation in disease incidence (\%) with application of different concentrations of Trichoderma spp. against Fusarium spp. under greenhouse conditions

$$
\mathbf{0} 1 \times 10^{8}(\mathrm{cfu} / \mathrm{ml}) \quad \mathbf{v} 1 \times 10^{16}(\mathrm{cfu} / \mathrm{ml}) \quad \mathbf{0} 1 \times 10^{24}(\mathrm{cfu} / \mathrm{ml})
$$

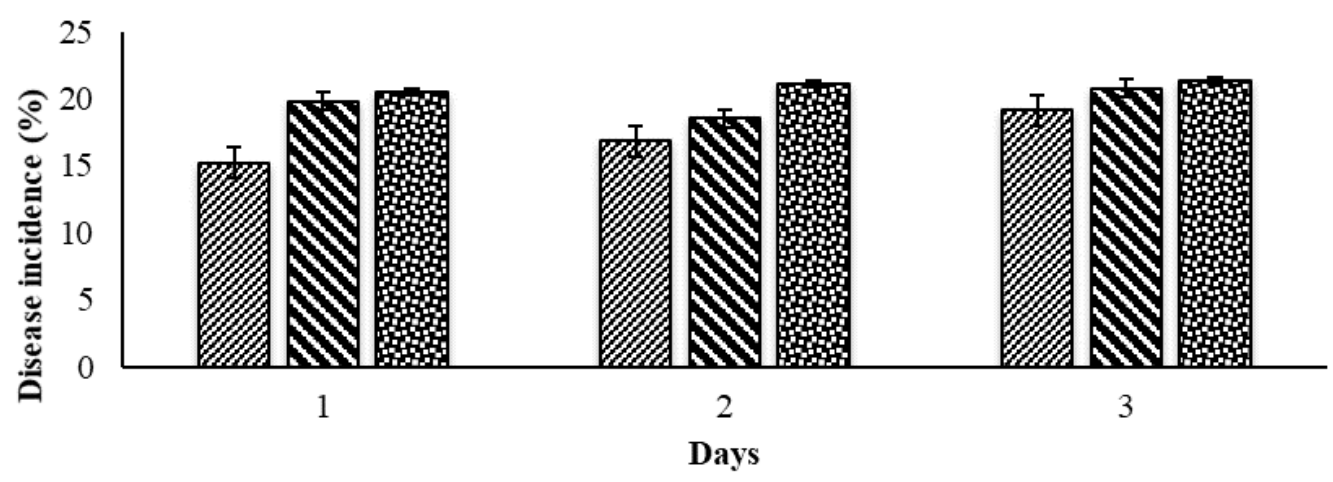

Figure 2. Variation in disease incidence after the application of Trichoderma spp. against Fusarium spp. under greenhouse conditions at various days

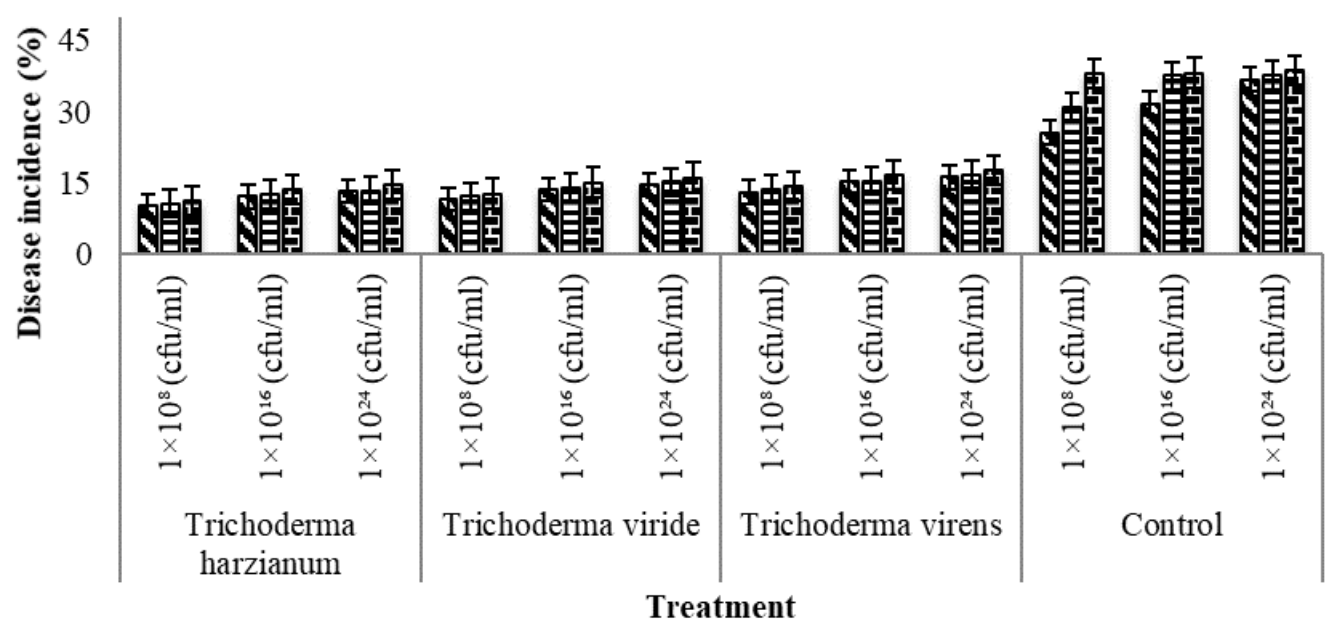

Figure 3. Variation in disease incidence (\%) with different treatments of Trichoderma spp. against Fusarium spp. under greenhouse conditions 


\section{Impact of various antagonists on gram wilt under in vitro conditions}

In lab study, various antagonists viz. Trichoderma harzianum, Trichoderma viride and Trichoderma virens significantly $(p \leq 0.05)$ inhibit $(\%)$ the fungal growth with respect to different time intervals. Inhibition (\%) was minimum $(11.96 \%)$ in case of Trichoderma virens followed by Trichoderma viride (10.50\%) and Trichoderma harzianum (8.96\%) as compared to control. Regarding various time intervals, maximum disease inhibition $(8.41 \%)$ was observed. Disease inhibition (\%) was at its peak at day $96 \mathrm{~h}(8.41 \%)$, whereas, minimum disease inhibition (\%) was at $24 \mathrm{~h}(7.41 \%)$ (Table 3). Non-significant $(p \leq 0.05)$ interaction was observed between treatments and time interval over inhibition of fungal growth.

Table 3. Impact of Trichoderma spp. against Fusarium spp. under lab condition

\begin{tabular}{c|c|c}
\hline Treatments (T) & \% Inhibition & LSD $(\boldsymbol{p} \leq \mathbf{0 . 0 5})$ \\
\hline Trichoderma harzianum & $8.96 \mathrm{C}$ & 0.66 \\
Trichoderma viride & $10.50 \mathrm{~B}$ & \\
Trichoderma virens & $11.96 \mathrm{~A}$ & \multirow{2}{*}{0.57} \\
Control & $0.00 \mathrm{D}$ & \\
\hline \multicolumn{2}{c}{ Hours (h) } \\
\hline 48 & $7.41 \mathrm{~B}$ & \\
\hline 96 & $7.73 \mathrm{~B}$ & \\
\hline
\end{tabular}

Any two means within a column followed by same letters are not significant at $p \leq 0.05$. * Significant at $p \leq 0.05 ; * *=$ Significant at $p \leq 0.01 ; \mathrm{NS}=$ Non-significant

\section{In vivo and in vitro disease management by using fungicides}

\section{Impact of various fungicides on gram wilt under in vitro conditions}

In in vitro study, ten fungicide chemicals from different chemical groups viz. Score, Topsin-M and Bavistan, Chlorothalonil, Stump, Big time, Champion, Valvet, CurzateMS and Co-Oxy applied at various concentrations significantly $(p \leq 0.05)$ reduced the fungal growth $(\mathrm{mm})$ with respect to different days. Fungal growth $(\mathrm{mm})$ was minimum (6.46) in case of Score followed by Topsin-M (8.00), Bavistan (9.46), Chlorothalonil (11.00), Stump (12.50), Big time (14.00), Champion (15.46), Valvet (16.96), CurzateMS (18.46) and Co-Oxy (19.96) over control (42.37). Regarding various concentrations, maximum reduction in fungal growth (14.24) was observed where $100 \mathrm{ppm}$ concentration was applied as compared to $200 \mathrm{ppm}$ (16.07) and $300 \mathrm{ppm}$ (17.30). Reduction in fungal growth was at its peak at day $1^{\text {st }}$ (15.30), whereas, minimum reduction in fungal growth was at day 3 (16.59) (Table 4). Regarding interaction between treatments and concentrations revealed that maximum reduction in fungal growth $(\mathrm{mm})$ was assessed in case of score $(4.72,6.83,7.83)$, while, minimum reduction in fungal growth $(\mathrm{mm})$ was exhibited in case of control $(41.55,42,43.55)$ at $100 \mathrm{ppm}, 200 \mathrm{ppm}$ and $300 \mathrm{ppm}$ concentrations respectively. Interactive effect of treatments and days revealed that maximum reduction in fungal growth $(\mathrm{mm})$ was assessed in case of score $(5.88,6.27,7.22)$, while, minimum reduction in fungal growth 
$(\mathrm{mm})$ was exhibited in case of control $(41.22,42.61,43.27)$ at $1^{\text {st }}, 2^{\text {nd }}$ and $3^{\text {rd }}$ day respectively. Interaction between concentrations and days revealed that maximum reduction in fungal growth $(\mathrm{mm})$ was assessed in case of $100 \mathrm{ppm}(13.57,14.24,14.92)$, while, minimum reduction in fungal growth $(\mathrm{mm})$ was exhibited in case of $300 \mathrm{ppm}$ $(16.69,17.19,18.03)$ at $1^{\text {st }}, 2^{\text {nd }}$ and $3^{\text {rd }}$ day respectively (Figs. 4-6).

Table 4. Impact of different fungicides against wilt fungal pathogen under lab condition

\begin{tabular}{c|c|c}
\hline Treatments (T) & Fungal growth $(\mathbf{m m})$ & LSD $(\boldsymbol{p} \leq \mathbf{0 . 0 5})$ \\
\hline Score & $6.46 \mathrm{~K}$ & \\
Topsin-M & $8.00 \mathrm{~J}$ & \\
Bavistan & $9.46 \mathrm{I}$ & \\
Chlorothalonil & $11.00 \mathrm{H}$ & \\
Stump & $12.50 \mathrm{G}$ & \\
Big time & $14.00 \mathrm{~F}$ & \\
Champion & $15.46 \mathrm{E}$ & \\
Valvet & $16.96 \mathrm{D}$ & \\
Curzate-M8 & $18.46 \mathrm{C}$ & \\
Co-Oxy & $19.96 \mathrm{~B}$ & \\
Control & $42.37 \mathrm{~A}$ & \\
\hline Concentration $(\mathbf{C})$ & & \\
\hline $100 \mathrm{ppm}$ & $14.24 \mathrm{C}$ & \\
$200 \mathrm{ppm}$ & $16.07 \mathrm{~B}$ & \\
$300 \mathrm{ppm}$ & $17.30 \mathrm{~A}$ & \\
\hline Days $(\mathbf{D})$ & & \\
\hline 1 & $15.30 \mathrm{C}$ & \\
2 & $15.72 \mathrm{~B}$ & \\
3 & $16.59 \mathrm{~A}$ & \\
\hline LSD $(\boldsymbol{p} \leq \mathbf{0 . 0 5})$ & & $* 08$ \\
\hline $\mathrm{T} \times \mathrm{C}$ & & \\
$\mathrm{T} \times \mathrm{D}$ & & \\
$\mathrm{C} \times \mathrm{D}$ & & \\
\hline $\mathrm{C} \times \mathrm{D}$ & & \\
\hline
\end{tabular}

Any two means within a column followed by same letters are not significant at $p \leq 0.05 . *=$ Significant at $p \leq 0.05 ; * *=$ Significant at $p \leq 0.01 ; \mathrm{NS}=$ Non-significant

Ten fungicides Score, Topsin M, Baviston, Chlorothalonil, Stump, Big Time, Champion, Velvet, Curzate M8 and Co-oxy were checked out against Fusarium spp. by using Poison Food Technique (Nene and Thapliyal, 1982). These ten fungicides were evaluated at three concentrations (100, 200 and $300 \mathrm{ppm})$. Effectiveness of fungicides was tested in inhibiting fungus growth. There was a significant decrease in mycelial growth with an increase in concentration of fungicide. Score followed by Topsin-M, and Bavistan was observed most effective fungicide and Curzate M8 and Co-oxy were found least effective fungicides against all the isolates in decreasing the fungus radial growth. Intermediate response in suppressing $F$. oxysporum growth was observed by the use of Chlorothalonil, Stump, Big Time, Champion and Velvet. In field study, various 
antagonists viz. Score, Topsin-M and Bavistan applied at various concentrations significantly $(p \leq 0.05)$ reduced the disease incidence $(\%)$ with respect to different days. Disease incidence $(\%)$ was minimum $(8.46 \%)$ in case of Score followed by Topsin-M $(10.00 \%)$ and Bavistan (11.46\%) over control (44.37\%). Regarding various concentrations, maximum reduction in disease incidence $(17.16 \%)$ was observed where $100 \mathrm{ppm}$ concentration was applied as compared to $200 \mathrm{ppm}(18.61 \%)$ and $300 \mathrm{ppm}$ $(19.94 \%)$. Reduction in disease incidence was at its peak at day $1^{\text {st }}(17.84 \%)$, whereas, minimum reduction in disease incidence was at day 3 (19.36\%) (Table 5). Regarding interaction between treatments and concentrations revealed that maximum reduction in disease incidence $(\%)$ was assessed in case of score $(6.72 \%, 8.83 \%, 9.83 \%)$, while, minimum reduction in disease incidence was exhibited in case of control $(43.55 \%, 44 \%$, $45.55 \%$ ) at $100 \mathrm{ppm}, 200 \mathrm{ppm}$ and $300 \mathrm{ppm}$ concentrations. Interactive effect of treatments and days revealed that maximum reduction in disease incidence (\%) was assessed in case of score $(7.88 \%, 8.27 \%, 9.22 \%)$, while, minimum reduction in disease incidence was exhibited in case of control $(43.22 \%, 44.61 \%, 45.27 \%)$ at $1^{\text {st }}, 2^{\text {nd }}$ and $3^{\text {rd }}$ day. Interaction between concentrations and days revealed that maximum reduction in disease incidence (\%) was assessed in case of $100 \mathrm{ppm}(16.29 \%, 17.25 \%, 17.95 \%)$, while, minimum reduction in disease incidence was exhibited in case of $300 \mathrm{ppm}$ $(19.33 \%, 19.83 \%, 20.66 \%)$ at $1^{\text {st }}, 2^{\text {nd }}$ and $3^{\text {rd }}$ day. Interaction between treatments, concentrations and days showed that disease incidence (\%) (6.16\%) was minimum where score applied with $100 \mathrm{ppm}$ concentration at $1^{\text {st }}, 2^{\text {nd }}$ and $3^{\text {rd }}$ day. Disease incidence $(\%)$ was maximum in control as compared to all other treatments at various days (Figs. 7-10).

Table 5. Impact of various fungicides against fungal pathogen under field condition

\begin{tabular}{|c|c|c|}
\hline Treatments (T) & Disease incidence (\%) & $\operatorname{LSD}(p \leq 0.05)$ \\
\hline Score & $8.46 \mathrm{D}$ & \multirow{4}{*}{0.15} \\
\hline Topsin-M & $10.00 \mathrm{C}$ & \\
\hline Bavistan & $11.46 \mathrm{~B}$ & \\
\hline Control & $44.37 \mathrm{~A}$ & \\
\hline \multicolumn{3}{|c|}{ Concentration (C) } \\
\hline 100 ppm & $17.16 \mathrm{C}$ & \\
\hline 200 ppm & $18.61 \mathrm{~B}$ & 0.13 \\
\hline $300 \mathrm{ppm}$ & $19.94 \mathrm{~A}$ & \\
\hline \multicolumn{3}{|c|}{ Days (D) } \\
\hline 1 & $17.84 \mathrm{C}$ & \\
\hline 2 & $18.51 \mathrm{~B}$ & 0.13 \\
\hline 3 & $19.36 \mathrm{~A}$ & \\
\hline \multicolumn{3}{|c|}{$\operatorname{LSD}(p \leq 0.05)$} \\
\hline $\mathrm{T} \times \mathrm{C}$ & \multicolumn{2}{|c|}{$* *$} \\
\hline $\mathrm{T} \times \mathrm{D}$ & \multicolumn{2}{|c|}{$* *$} \\
\hline $\mathrm{C} \times \mathrm{D}$ & \multicolumn{2}{|c|}{$*$} \\
\hline $\mathrm{T} \times \mathrm{C} \times \mathrm{D}$ & \multicolumn{2}{|c|}{$* *$} \\
\hline
\end{tabular}

Any two means within a column followed by same letters are not significant at $p \leq 0.05$. * Significant at $p \leq 0.05 ; * *=$ Significant at $p \leq 0.01 ; \mathrm{NS}=$ Non-significant 


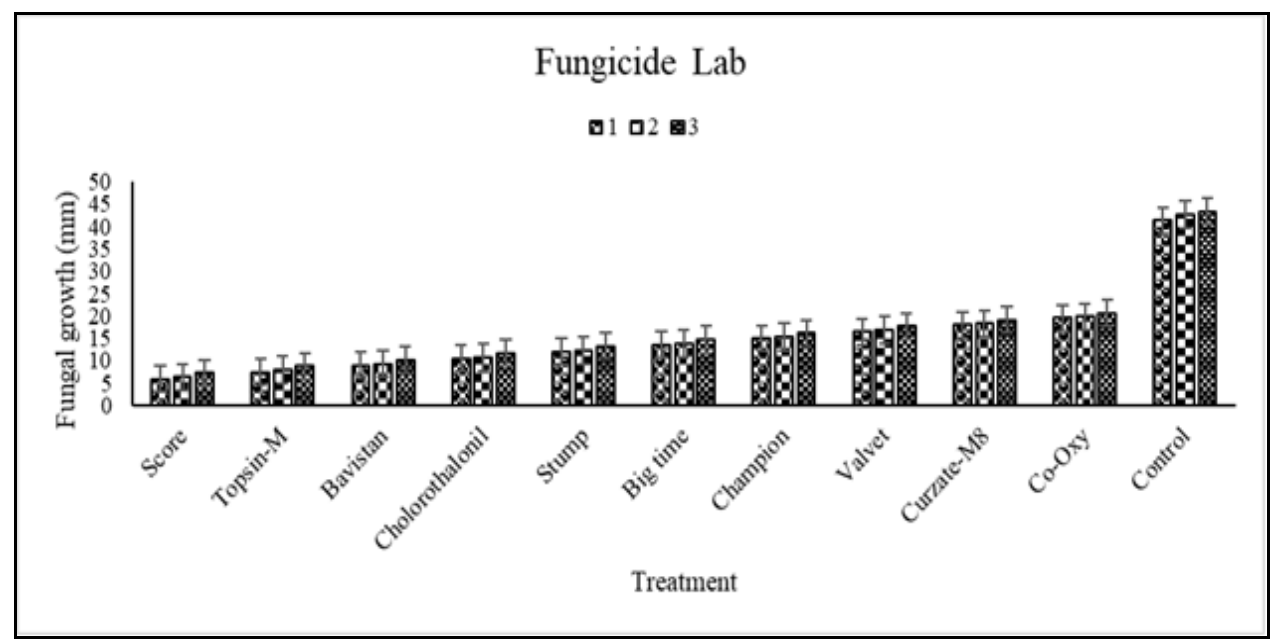

Figure 4. Variation in growth inhibition with different treatments of ten fungicides against fungal pathogen under lab conditions

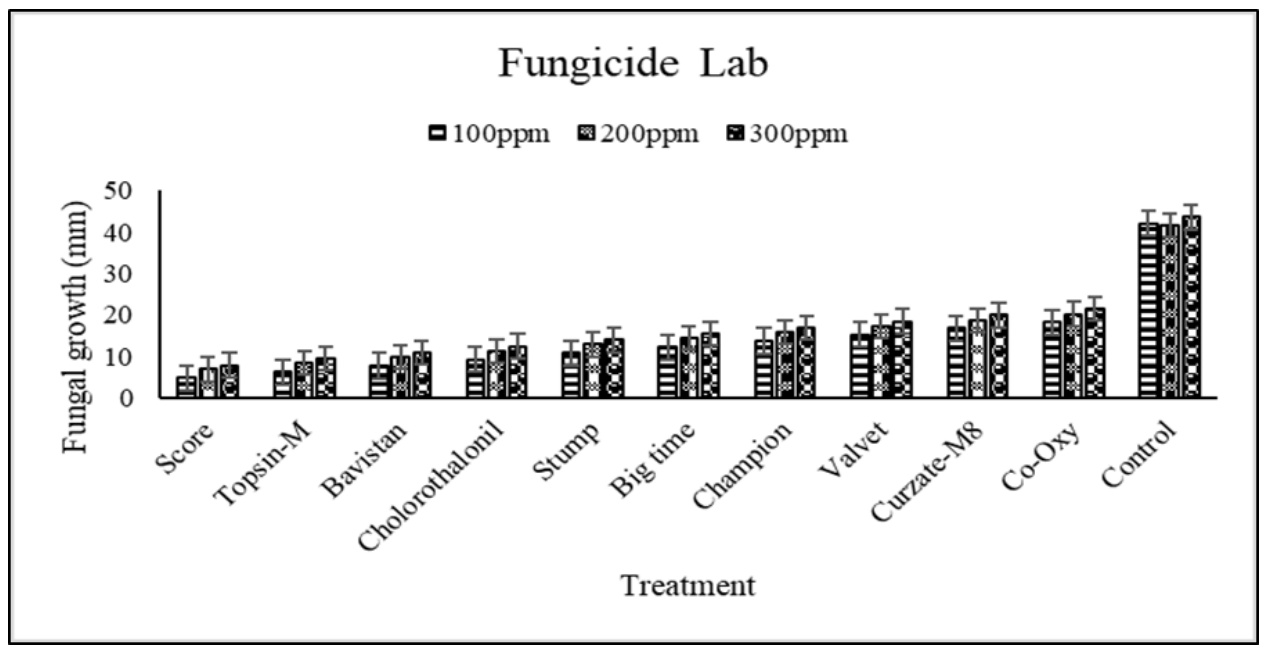

Figure 5. Variation in growth inhibition with different concentrations of fungicides against fungal pathogen under lab conditions

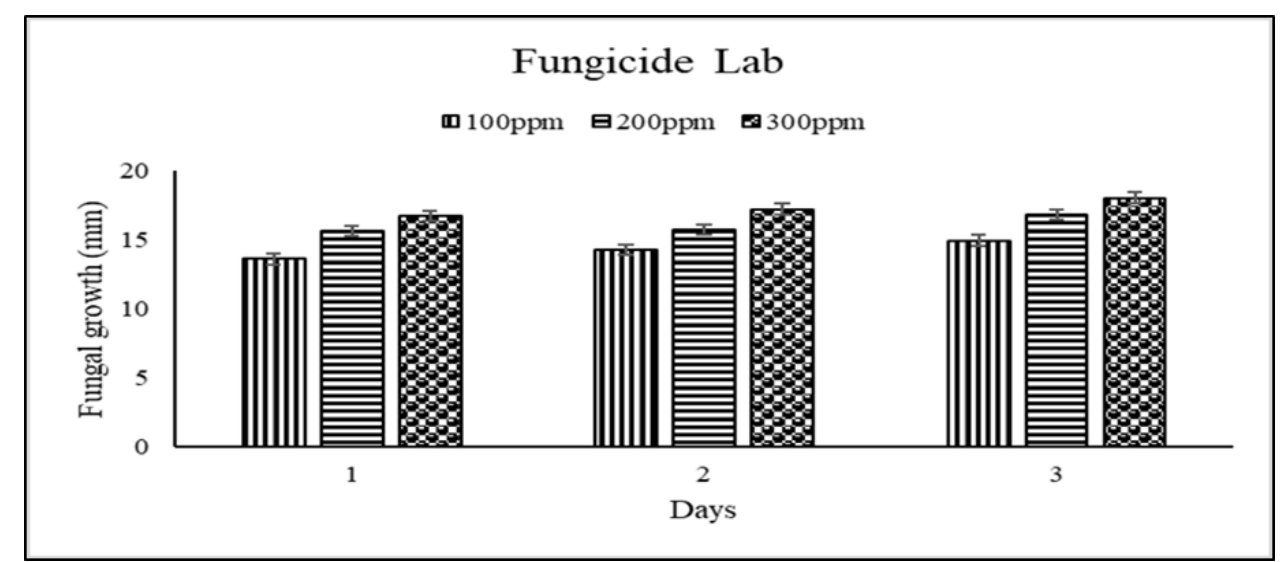

Figure 6. Variation in growth inhibition after different days $(1=7,2=14 \& 3=21)$ of application fungicides against fungal pathogen under lab conditions 


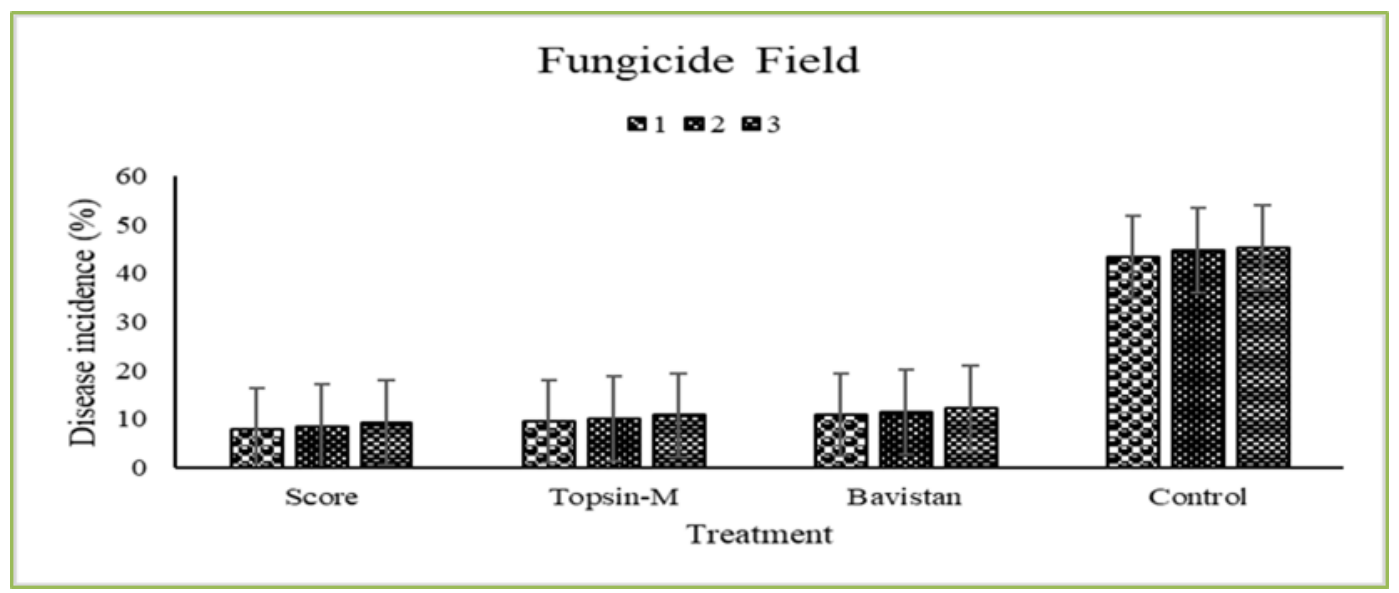

Figure 7. Variation in disease incidence with different concentrations of fungicides against fungal pathogen under field conditions

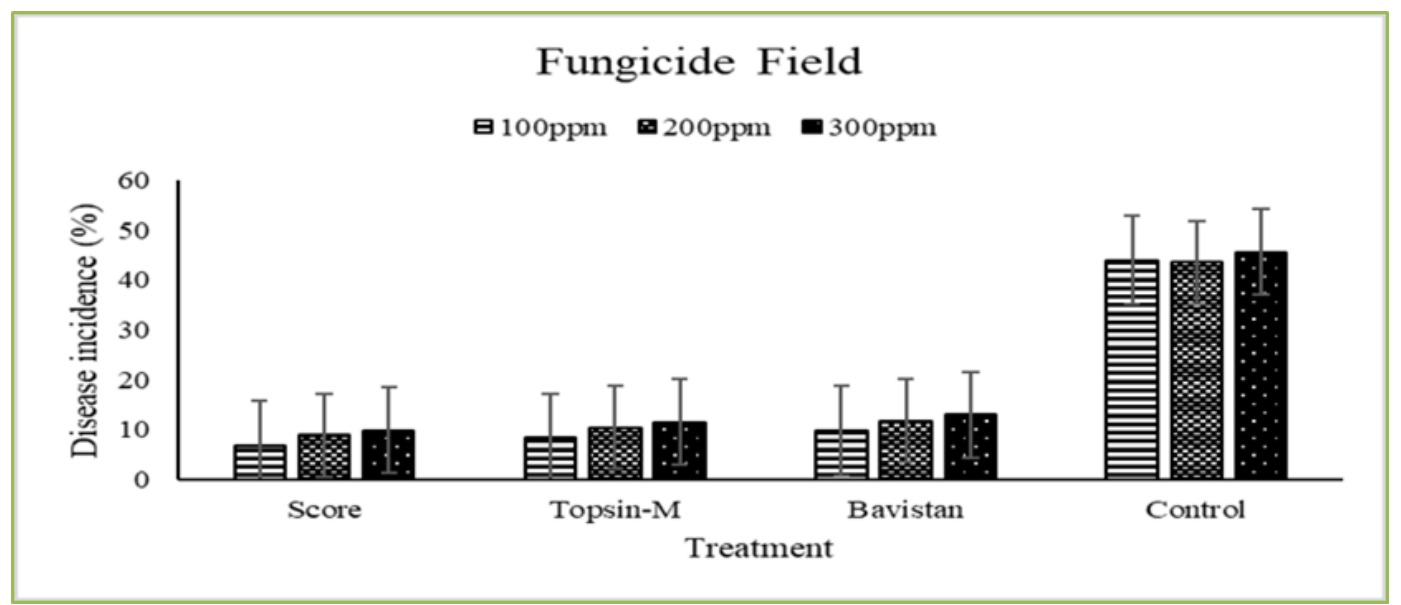

Figure 8. Variation in disease incidence with different treatments of fungicides against fungal pathogen under field conditions

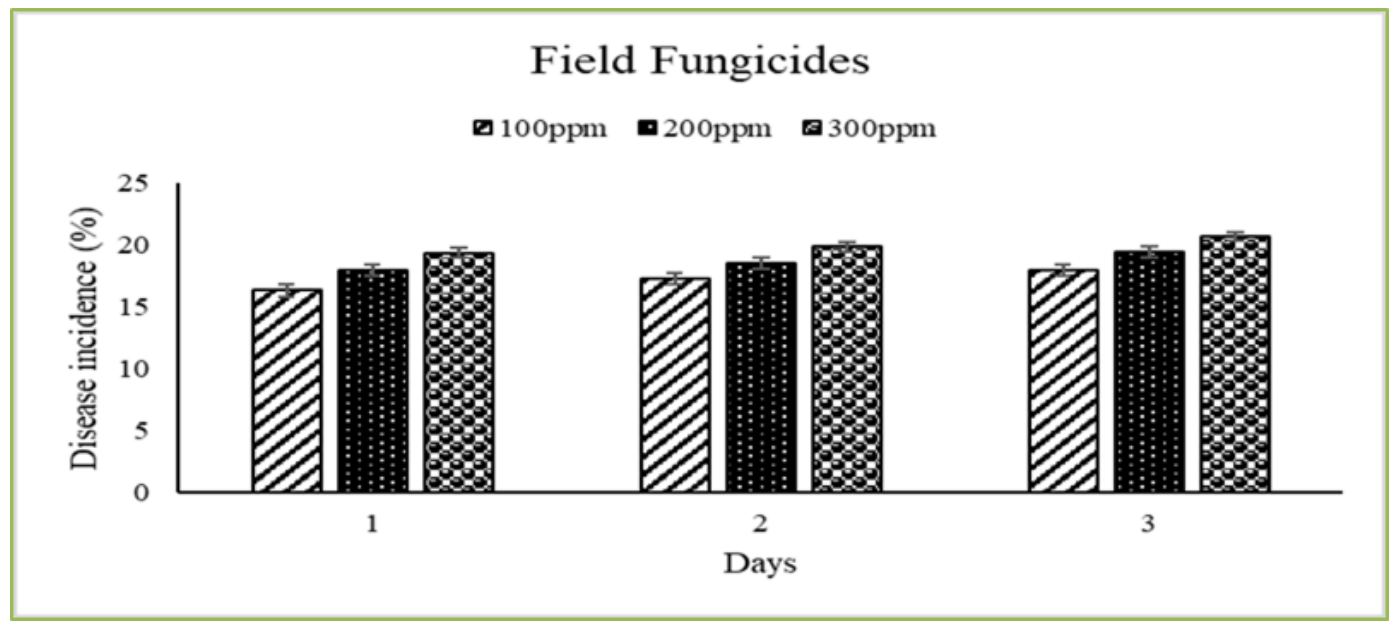

Figure 9. Variation in disease incidence after different days $(1=7,2=14 \& 3=21)$ of application of most effective fungicides against fungal pathogen under field conditions 


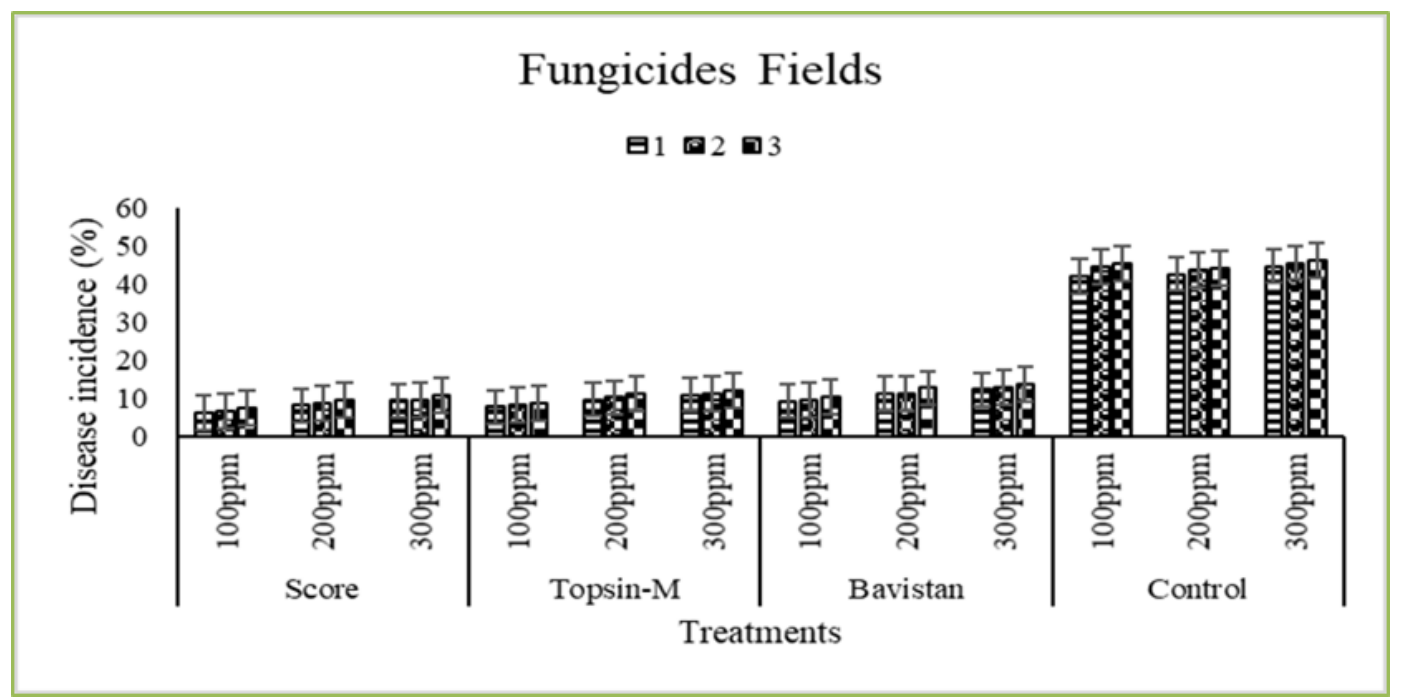

Figure 10. Variation in disease incidence with different treatments fungicides against fungal pathogen under field conditions

\section{Discussion}

Screening of 20 chickpea germplasms was done to find out the most resistant varieties against Fusarium spp. in 2017 and 2018. Two varieties (Balkasar and C-727) were highly resistant, six lines were resistant, four lines were moderately resistant, five varieties were susceptible and three varieties were highly susceptible. Such type of results has also been shown by another worker (Chaudhry et al., 2006, 2007; Infantino et al., 2006). The best procedure to infect the lines at seedling stage is by infestation of the soil with Fusarium inoculum and completely covers the surface of soil in the pots. By this method pathogen grows and infects the host more sharply (Gurha and Dubey, 1982). This technique is time saving and most effective as compare to other procedures. This technique was followed by (Sugha et al., 1991). Three fungal antagonists (Trichoderma harzianum, Trichoderma viride and Trichoderma virens) were evaluated against virulent pathogens in which Trichoderma harzianum showed maximum inhibition under lab and field conditions. My results showed similarity with the results of Akrami et al. (2013). These results also have synchronization with other researches (Jayalakshmi et al., 2009). Most competitive pathogens grow near the rootzone of chickpea and increase their colonies due to which fungal antagonists help to inhibit their action on plant (Benhamou et al., 2002). Tricoderma spp. is very beneficial against fungal pathogens because of their multiple actions. My results are also close to this research which shows that Trichoderma harzianum is very effective biocontrol agent because of its production of antibics, production of enzymes chitinase, has ability to solubilize inorganic compounds and also inactivate pathogenic enzymes (Harman, 2006). Ten fungicides (Score, Topsin M, Baviston, Chlorothalonil, Stump, Big Time, Champion, Velvet, Curzate M8 and Co-oxy) were evaluated against virulent pathogens in which Score showed maximum inhibition of isolates of Fusarium spp. which were followed by Topsin $\mathrm{M}$ and Baviston under lab conditions while on the other hand Score inhibited maximum fungal growth under field conditions. Response of my systemic fungicides showed relatedness with the results of Dahal and Shrestha (2018) in which sensitivity of Fusarium spp. was evaluated by using different fungicides like 
carbendazim, chlorothalonil and dithane M-45. Maximum mycelial growth was inhibited by carbendazim which was up to $98.23 \%$ at all concentrations $100,150,200$ ppm. Minimum inhibition was obtained by dithane M-45 which was up to $27.43 \%$ at $150 \mathrm{ppm}$. Intermediate inhibition was observed chlorothalonil $(65.78 \%)$ at $150 \mathrm{ppm}$ concentration. My results also correlate with the following references. Dithane M-45 is least effective as compare to the other examined fungicides. Some fungicide acts systemically in pathogens has more efficacy like carbendazim as compare to other nonsystemic chemicals like mancozeb (Khola et al., 2016). Carbendazim is very effective against fusarium which causes wilt in chickpea at every concentration Luz et al. (2007), Maheshwari et al. (2008), Singh et al. (2010), and Somu et al. (2014). Carbendazim also inhibits the growth of $F$. solani (Narayanan et al., 2015). Some researcher used carbendazim for the reduction of Foc (Subhani et al., 2011) and some used it for complete inhibition of Foc (Maitlo et al., 2014). Chlorothalonil is least effective as compare to carbendazim and more effective as compare to dithane M-45. Chlorothalonil at $0.1 \%$ inhibits fusarium growth in less than carbendazim at $0.2 \%$ (Manasa et al., 2017). Chlorothalonil binds to proteins to inhibit the catalytic activity of enzyme. This chemical binds to glyceraldehyde-3-phosphate (GAP) and reacts with sulfhydryl which plays an important role in binding to GAP (Long and Siegel, 1975). Mancozeb inhibits the mycelia growth up to $66 \%$ by using $200 \mathrm{ppm}$ (Singh et al., 2010). In some other researches it is reported that dithane M-45 fully inhibits the growth of Fusarium spp. at 200 ppm concentration (Dabbas et al., 2008).

\section{Conclusion}

Integrated disease management of chickpea wilt helped in finding out the appropriate management strategies against Fusarium spp. associated with chickpea wilt. Growing of resistant varieties would increase the chickpea yield by reducing the disease incidence. The future management strategies of this pathogen would be better with the combination of biological and chemical control.

Acknowledgments. The researcher and her team thankful for financial assistance under the project funded by USPCAS-AFS $\neq 935$ at UAF and this article is a part of PhD dissertation of Kaneez Fatima, a PhD Scholar at Department of Plant Pathology, UAF.

\section{REFERENCES}

[1] Ayyub, M., Khan, S., Ahmad, R., Iftikhar, K. (2003): Screening of chickpea germplasm for the sources of resistance against chickpea wilt (Fusarium oxysporum f. sp. ciceris). Pakistan Journal Phytopathology 15: 25-7.

[2] Akrami, M., Khiavi, H. K., Shikhlinski, H., Khoshvaghtei, H. (2013): Bio controlling two pathogens of chickpea Fusarium solani and Fusarium oxysporum by different combinations of Trichoderma harzianum, Trichoderma asperellum and Trichoderma virens under field condition. - International Journal of Microbiology Research 1(2): 052055 .

[3] Atta, B. M., Shah, T. M. (2009): Stability analysis of elite chickpea genotypes tested under diverse environments. - Australian Journal of Crop Science 3: 249-256. 
[4] Benhamou. N., Garand, C., Goulet, A. (2002): Ability of nonpathogenic Fusarium oxysporum strain Fo47 to induce resistance against Pythium ultimum infection in cucumber. - Applied and Environmental Microbiology 68(8): 4044-4060.

[5] Chaudhry, M. A., Muhammad, F., Afzal, M. (2006): Screening of chickpea germplasm against fusarium wilt. - J. Agric. Res. 44(4).

[6] Chaudhry, M. A., Ilyas, M. B., Muhammad, F., Ghazanfar, M. U. (2007): Sources of resistance in chickpea germplasm against Fusarium wilt. - Mycopath 5(1): 17-21.

[7] Dahal, N., Shrestha, R. K. (2018): Evaluation of efficacy of fungicides against Fusarium oxysporum f. sp. Lentis in vitro at Lamjung, Nepal. - Journal of the Institute of Agriculture and Animal Science 35: 105-112.

[8] Dabbas, M., Srivastava, J., Rai. M. (2008): IDM for wilt disease of table pea. - Annals of Plant Protection Sciences 16: 156-158.

[9] Gupta, R. P., Katiyar, R. P., Singh, D. P. (1988): Seed treatment with Bavistin and Rhizobium and its effect on wilt incidence, nodulation and yield of chickpea. - Pesticides 22: 9-10.

[10] Gurha, S. N., Kamthan, K. P., Misra, D. P. (1982): Reaction of some exotic and indigenous cultivars of chickpea ( $C$. arietinum L.) against Sclerotium rolfsii Sacc. Madras Agric. J. 69: 471-473.

[11] Graham, P. H., and Vance, C. P. (2003): Legumes: importance and constraints to greater use. - Plant Physiology 131: 872-877.

[12] Harman, G. E. (2006): Overview of mechanisms and uses of Trichoderma spp. Phytopathology 96: 190-194.

[13] Haware, M. P. (1990): Fusarium wilt and other important diseases of chickpea in the Mediterranean area. - Options Méditerranéennes Série A: Séminaires Méditerranéens 61.

[14] Haware, M. P., Nene, Y. L. (1980): Influence of wilt at different stages on the yield loss in chickpea. - Tropical Grain Legume Bulletin 19: 38-44.

[15] Haware, M. P., Nene, Y. L., Mathur, S. B. (1986): Seed borne diseases of chickpea. Technical Bulletin. No.1, ICRISAT.

[16] Haware, M. P., Nene, Y. L., Natarajan, M. (1996): Survival of Fusarium oxysporum f. sp. ciceri. - Plant Disease 66: 809-810.

[17] Infantino, A., Kharrat, M., Riccioni, L., Clarice Coyne, J., Kevin, E., McPhee, J., Niklaus., Grünwald. (2006): Screening techniques and sources of resistance to root diseases in cool season food legumes. - Euphytica 147: 1-2, 201.

[18] Jayalakshmi. S. K., Raju, S., Usha-Rani, S., Benagi, V. I., Sreeramulu, K. (2009): Trichoderma harzianum $\mathrm{L} 1$ as a potential source for lytic enzymes and elicitor of defense responses in chickpea (Cicer arietinum L.) against wilt disease caused by Fusarium oxysporum f. sp. ciceri. - Australian Journal of Crop Science-3(1): 44-52.

[19] Khan, I. A., Alam, S. S., Haq, A., Jabbar, A. (2002): Selection for resistant to wilt in relation with phenols in Chickpea. - International Chickpea and Pigeonpea Newsletter 9: 19-20.

[20] Khola, R., Chaudhary, A. R., Farah, N., Ghulam. S. (2016): Management of vascular wilt of lentil through host plant resistance, biological control agents and chemicals. - Pakistan Journal of Botany 48(5): 2085-2092.

[21] Long, J. W., Siegel, M. R. (1975): Mechanism of action and fate of the fungicide chlorothalonill $(2,4,5,6$-tetrachoroisophthalonitrile) in biological systems. 2. In vitro reactions. - Chemico-Biological Interactions 10(6): 383-394.

[22] Luz, C., Netto, M. C. B., Rocha, L. F. N. (2007): In vitro susceptibility to fungicides by invertebrate- pathogenic and saprobic fungi. - Mycopathologia 164: 39-47.

[23] Maheshwari, S. K., Bhat, N. A., Masoodi, S. D., Beig, M. A. (2008): Chemical Control of Lentil Wilt caused by Fusarium oxysporum f. sp. lentis. - Annual Plant Protection Science 16(2): 419-421. 
[24] Maitlo, S. A., Syed, R. N., Rustamani, M. A., Khuhro, R. D., Lodhi, A. M. (2014): Comparative efficacy of different fungicides against fusarium wilt of chickpea (Cicer arietinum L.). - Pakistan Journal of Botany 46(6): 2305-2312.

[25] Nema, K. G., Khare, M. N. (1973): A conspectus of wilt Bengal gram in Madhya Pradesh. Symposium on wilt problem and breeding for wilt resistance in Bengal gram. Indian Agricultural Research Institute, New Dehli (Abst).

[26] Manasa, B. G., Somashekara, Y. M., Shankara, K., Swamy, C. (2017): Efficacy of fungicides in control of Fusarium oxysporum f. sp. dianthi, the cause of wilt in carnation. - International Journal of Current Microbiology and Applied Sciences 6(10): 2559-2565.

[27] Millan, T., Clarke, H. J., Siddique, K. H., Buhariwalla, H. K., Gaur, P. M., Kumar, J., Gil, J., Kahl, G., Winter, P. (2006): Chickpea molecular breeding: new tools and concepts. Euphytica147: 81-103.

[28] Narayanan, P., Vanitha, S., Rajalakshmi, J., Parthasarathy, S., Arunkumar, K., Nagendran, K., Karthikeyan, G. (2015): Efficacy of bio-control agents and fungicides in management of mulberry wilt caused by Fusarium solani. - Journal of Biological Control 29(2): 107-114.

[29] Navas-Cortes, J. A., Hau, B., Jimenez-Diaz, R. M. (2000): Yield loss in chickpea in relation to development to Fusarium wilt epidemics. - Phytopatholology 90: 1269-1278.

[30] Nene, Y. L., Thaplyal, P. N. (1982): Fungicides in plant disease control. - Oxford and IBH Publ. Comp., New Delhi.

[31] Rehman, A., Imran, M., Mehboob, S., Khan, N. A., Alam, W., Riaz, K. (2018): Etiology, pathogenicity and management of collar rot in cockscomb (Celosia aregentea). - Int. J. Agric. Biol., 17: 9-14.

[32] Sharma, K. D., Muehlbauer, F. J. (2007): Fusarium wilt of chickpea: physiological specialization, genetics of resistance and resistance gene tagging. - Euphytica 157: 1-14.

[33] Singh, V. K., Naresh, P., Biswas, S. K., Singh, G. P. (2010): Efficacy of fungicides for management of wilt disease of lentil caused by Fusarium oxysporum $\mathrm{f}$ sp. lentis. - Annals of Plant Protection Sciences 18(2): 411-414.

[34] Somu, R., Thammaiah, N., Swami, G. S. K., Kulkarni, M. S., Devappa, V. (2014): In vitro evaluation of fungicides against Fusarium oxysporum f. sp. cubense. - International Journal of Plant Protection 7(1): 221-224.

[35] Subhani, M. N., Sahi, S. T., Hussain, S., Ali, A., Iqbal, J., Hameed, K. (2011): Evaluation of various fungicides for the control of gram wilt caused by Fusarium oxysporum f. sp. ciceri. - African Journal of Agricultural Research 6: 4555-4559.

[36] Sugha, S. K., Sharma, B. K., Tyagi, P. D. (1991): A modified technique for screening chickpea (Cicer arietinum) varieties against collar rot caused by Scerotium rolfsii. Indian J. Agric. Sci. 61(4): 289-290.

[37] Vincent, J. M. (1947): Distortions of fungal hyphae in the presence of certain inhibitors. Phytopathology 48: 268-270. Crossref.

[38] Yan, J., Yuan, S., Jiang, L., Ye, X., Bun, T., Wu, Z. (2015): Plant antifungal proteins and their applications in agriculture. - Appl. Microbiol. Biotechnol. 99: 4961-4981.

[39] Zamani, M., Motallebi, M., Rostamian, A. (2004): Characterization of Iranian isolates of Fusarium oxysporum on the basis of RAPD analysis, virulence and vegetative compatibility. - Journal of Phytopathology 152: 449-53. 